\title{
PENGOLAHAN LIMBAH CAIR DOMESTIK DENGAN BIOFILTER AEROB MENGGUNAKAN MEDIA BIOBALL DAN TANAMAN KIAMBANG
}

\author{
Mega Filliazati ${ }^{1}$, Isna Apriani ${ }^{1}$, Titin Anita Zahara ${ }^{2}$ \\ ${ }^{1}$ Program Studi Teknik Lingkungan, Fakultas Teknik, Universitas Tanjungpura, Pontianak \\ ${ }^{2}$ Program Studi Kimia, Fakultas MIPA, Universitas Tanjungpura, Pontianak \\ Email : megafilliazati@gmail.com
}

\begin{abstract}
ABSTRAK
Air limbah domestik (greywater) merupakan air buangan yang berasal dari kegiatan dapur, toilet, wastafel dan sebagainya yang jika langsung dibuang ke lingkungan tanpa dilakukan pengolahan terlebih dahulu akan menyebabkan pencemaran dan dampak terhadap kehidupan di air. Salah satu upaya dalam mengelola limbah domestik yaitu dengan pengolahan biofilter aerob menggunakan media bioball dan tanaman kiambang. Tujuan dari penelitian ini untuk mengetahui efisiensi penurunan BOD, minyak dan lemak pada limbah rumah makan dengan pengolahan biofilter aerob menggunakan media bioball dan tanaman kiambang. Proses penelitian ini meliputi proses pembiakan bakteri (seeding) selama 2 minggu, dilanjutkan dengan aklimatisasi selama 3 hari dengan arah aliran down flow-up flow dan dilakukan secara duplo di Laboratorium menggunakan reaktor yang terbuat dari kaca dengan dimensi tertentu, bioball dan tanaman kiambang dan debit 0,34 ml/detik menghasilkan efisiensi penurunan BOD sebesar 68,98\% dari konsentrasi awal BOD 785,5 mg/l menjadi 235,29 mg/l. Sedangkan efisiensi penurunan minyak lemak sebesar 96,60\% dari konsentrasi awal $5213 \mathrm{mg} / \mathrm{l}$ menjadi 177,5 $\mathrm{mg} / \mathrm{l}$. Dari hasil penelitian yang dilakukan, pengolahan dengan bioball dan tanaman kiambang mampu menurunkan parameter khususnya BOD dan minyak lemak, tetapi nilai tersebut masih diatas baku mutu Keputusan Menteri Lingkungan Hidup No. 112 Tahun 2003.
\end{abstract}

Kata Kunci : Biofilter aerob, bioball, tanaman kiambang

\begin{abstract}
Domestic wastewater ( greywater) is waste water that comes from the activities of the kitchen, toilet, sink and others. So that if directly discharged into environment without any treatment in advance, it will cause pollution and impacts on aquatic life. An effort in managing domestic waste is by using aerobic biofilter processing bioball and kiambang plant. The aim of this research are determining the efficiency of BOD reduction, waste oils and fats at a restaurant using aerobic biofilter to kiambang plants and bioball. The research process includes the process of bacterial culture ( seeding) for 2 weeks and continuing by acclimatization for 3 days with the direction of down flow to up flow. Afterward, it performed in duplicating in the laboratory using a reactor made of glass with a certain dimensio, bioball and kiambang plant and discharge $0.34 \mathrm{ml} / \mathrm{sec}$ result in BOD removal efficiency of $68,98 \%$ of the initial BOD concentration of 785,5 $\mathrm{mg} / \mathrm{I}$ to $235,29 \mathrm{mg} / \mathrm{I}$. While the oil removal efficiency of $96,60 \%$ of the fatty initial concentration of $5213 \mathrm{mg} / \mathrm{I}$ to $177,5 \mathrm{mg} / \mathrm{I}$. Based on the results of research conducted, waste water treatment with bioball and processing with Kiambang plant afford of reducing kiambang particular parameter BOD and fatty oils. But the value is still above the quality standard of the Environment Ministers's Decision No. 112 of 2003.
\end{abstract}

Keywords: Aerob Biofilter, bioball, kiambang plants

\section{Latar Belakang}

Setiap aktivitas yang dilakukan manusia akan menghasilkan limbah, limbah ini dalam skala kecil tidak akan menimbulkan masalah karena alam memiliki kemampuan untuk menguraikan kembali komponen-komponen yang terkandung dalam limbah. Namun bila terakumulasi dalam skala besar, akan timbul permasalahan yang dapat menggangu keseimbangan lingkungan hidup.

Permasalahan lingkungan saat ini yang dominan adalah limbah cair yang berasal dari hasil kegiatan rumah tangga dan industri. Limbah cair yang tidak dikelola akan menimbulkan dampak pada perairan. Pengelolaan limbah cair dalam proses produksi dimaksudkan untuk meminimalkan limbah yang terjadi, serta untuk menghilangkan atau menurunkan kadar bahan pencemar yang terkandung di dalam perairan. 
Berdasarkan Keputusan Menteri Lingkungan Hidup No. 112 Tahun 2003, air limbah domestik terdiri dari parameter BOD, TSS, pH, minyak dan lemak yang apabila keseluruhan parameter tersebut dibuang langsung ke badan penerima, maka akan mengakibatkan pencemaran air. Oleh karena itu sebelum dibuang ke badan penerima air, terlebih dahulu harus diolah sehingga dapat memenuhi standar air yang baik.

Salah satu upaya mengolah limbah domestik (greywater) dengan cara sederhana yaitu dengan pengolahan biofilter aerob menggunakan media bioball dan tanaman, dalam hal ini tanaman yang digunakan adalah tanaman kiambang, pengolahan dengan biofilter aerob ini merupakan teknologi pengolahan air limbah rumah makan yang murah, mudah operasinya serta hemat energi.

Konsep teknologi pengolahan dengan biofilter aerob merupakan suatu istilah dari reaktor yang dikembangkan dengan prinsip mikroba tumbuh dan berkembang menempel pada suatu media filter dan membentuk biofilm (attached growth). Pengolahan ini adalah pengolahan yang sangat mudah dan sangat murah dari segi operasional. Biofilter dapat digunakan untuk air limbah dengan beban BOD yang cukup besar dan dapat menghilangkan padatan tersuspensi (SS) dengan baik. (Wijeyekoon et al, 2000)

\section{Tinjauan Pustaka}

A. Limbah Domestik

Limbah cair baik domestik maupun non domestik mempunyai beberapa karakteristik sesuai dengan sumbernya, karakteristik limbah cair dapat digolongkan pada karakteristik fisik, kimia, dan biologi sebagai berikut (Metcalf and Eddy, 2003) :

1. Karakteristik Fisika

Karakteristik fisika ini terdiri daribeberapa parameter, diantaranya :

a. Total Solid (TS)

Padatan terdiri dari bahan padat organik maupun anorganik yang dapat larut, mengendap atau tersuspensi. Bahan ini pada akhirnya akan mengendap di dasar air sehingga menimbulkan pendangkalan pada dasar badan air penerima

b. Total Suspended Solid (TSS)

Merupakan jumlah berat dalam $\mathrm{mg} / \mathrm{l}$ kering lumpur yang ada didalam air limbah setelah mengalami penyaringan dengan membran berukuran 0,45 mikron.

c. Warna.

Pada dasarnya air bersih tidak berwarna, tetapi seiring dengan waktu dan menigkatnya kondisi anaerob,warna limbah berubah dari yang abu-abu menjadi kehitaman.

d. Kekeruhan

Kekeruhan disebabkan oleh zat padat tersuspensi, baik yang bersifat organik maupun anorganik, serta menunjukkan sifat optis air yang akan membatasi pencahayaan kedalam air.

e. Temperatur

Merupakan parameter yang sangat penting dikarenakan efeknya terhadap reaksi kimia, laju reaksi, kehidupan organisme air dan penggunaan air untuk berbagai aktivitas seharihari.

f. Bau

Disebabkan oleh udara yang dihasilkan pada proses dekomposisi materi atau penambahan substansi pada limbah.

2. Karateristik Kimia

a. Biological Oxygen Demand (BOD) 
Biological oxygen demand atau kebutuhan oksigen biologis adalah jumlah oksigen yang dibutuhkan oleh mikroorganisme di dalam air lingkungan untuk memecah atau mendegradasi atau mengoksidasi limbah organik yang terdapat didalam air.

b. Chemical Oxygen Demand (COD)

Merupakan jumlah kebutuhan oksigen dalam air untuk proses reaksi secara kimia guna menguraikan unsur pencemar yang ada. COD dinyatakan dalam ppm (part per milion). (Metcalf and Eddy, 2003)

c. Protein

Protein merupakan bagian yang penting dari makhluk hidup, termasuk di dalamnya tanaman, dan hewan bersel satu. Di dalam limbah cair, protein merupakan unsur penyabab bau, karena adanya proses pembusukan dan peruraian oleh bakteri. (Metcalf and Eddy, 2003)

d. Karbohidrat

Karbohidrat antara lain : gula, pati, sellulosa dan benang-benang kayu terdiri dari unsur C, H, dan O. Gula dalam limbah cair cenderung terdekomposisi oleh enzim dari bakteribakteri tertentu dan ragi menghasilkan alkohol dan gas $\mathrm{CO} 2$ melalui proses fermentasi.

e. Minyak dan Lemak

Minyak dan lemak merupakan bahan pencemar yang banyak ditemukan di berbagai perairan, salah satu sumber pencemarnya adalah dari agroindustri.

f. Detergen

Deterjen termasuk bahan organik yang sangat banyak digunakan untuk keperluan rumah tangga, hotel, dan rumah sakit. Fungsi utama deterjen adalah sebagai pembersih dalam pencucian, sehingga tanah, lemak dan lainnya dapat dipisahkan.

g. Derajat keasaman $(\mathrm{pH})$

Air normal yang memenuhi syarat untuk suatu kehidupan mempunyai pH sekitar 6,5 7,5. Air akan bersifat asam atau basa tergantung besar kecilnya $\mathrm{pH}$. Bila $\mathrm{pH}$ di bawah $\mathrm{pH}$ normal, maka air tersebut bersifat asam, sedangkan air yang mempunyai $\mathrm{pH}$ di atas $\mathrm{pH}$ normal bersifat basa.

\section{Karakteristik Biologi}

Karakteristik biologi digunakan untuk mengukur kualitas air terutama air yang dikonsumsi sebagai air minum dan air bersih. Parameter yang biasa digunakan adalah banyaknya mikroorganisme yang terkandung dalam air limbah. Pengolahan air limbah secara biologis dapat didefinisikan sebagai suatu proses yang melibatkan kegiatan mikroorganisme dalam air untuk melakukan transformasi senyawa-senyawa kimia yang terkandung dalam air menjadi bentuk atau senyawa lain. Mikroorganisme mengkonsumsi bahan-bahan organik membuat biomassa sel baru serta zat-zat organik dan memanfaatkan energi yang dihasilkan dari reaksi oksidasi untuk metabolismenya. (Metcalf and Eddy, 2003)

\section{B. Biofilter}

Proses pengolahan air limbah dengan proses biofilter dilakukan dengan cara mengalirkan air limbah ke dalam reaktor biologis yang telah diisi dengan media penyangga untuk pengembangbiakkan mikroorganisme dengan atau tanpa aerasi. Untuk proses anaerobik dilakukan tanpa pemeberian udara atau oksigen. Biofiler yang baik adalah menggunakan prinsip biofiltrasi yang memiliki struktur menyerupai saringan dan tersusun dari tumpukan media penyangga yang disusun baik secara teratur maupun acak di dalam suatu biofilter. Adapun fungsi dari media penyangga yaitu sebagai tempat tumbuh dan berkembangnya bakteri yang akan melapisi permukaan media membentuk lapisan massa yang tipis (biofilm) (Herlambang dan Marsidi, 2003). 


\section{Bioball}

Media bio-ball mempunyai keunggulan antara lain mempunyai luas spesifik yang cukup besar, pemasangannya mudah (random), sehingga untuk paket instalasi Pengolahan Air Limbah (IPAL) kecil sangat sesuai. Keunggulan dari media bioball yaitu karena ringan, mudah dicuci ulang, dan memiliki luas permukaan spesifik yang paling besar di bandingkan dengan jenis media biofilter lainnya, yaitu sebesar $200-240 \mathrm{~m}^{2} / \mathrm{m}^{3}$. Sedangkan jenis bioball yang dipilih adalah yang berbentuk bola dengan diameter $3 \mathrm{~cm}$ karena bioball jenis ini yang memiliki diameter paling kecil dan dengan bentuknya yang seperti bola (random packing) dapat meminimalkan terjadinya clogging (tersumbat). Bioball ini berfungsi sebagai tempat hidup bakteri - bakteri yang diperlukan untuk menjaga kualitas air. (Said, 2005)

\section{Biofilm}

Biofilm adalah kumpulan sel mikroorganisme, khususnya bakteri yang melekat di suatu permukaan dan diselimuti oleh pelekat karbohidrat yang dikeluarkan oleh bakteri. Biofilm terbentuk karena mikroorganisme cenderung menciptakan lingkungan mikro dan relung) mereka sendiri. Biofilm memerangkap nutrisi untuk pertumbuhan populasi mikroorganisme dan membantu mencegah lepasnya sel-sel dari permukaan pada sistem yang mengalir.

Apabila pada media terbentuk lapisan lendir yang berwarna hitam kecoklatan-coklatan serta tidak mudah terlepas dari media, maka dapat dipastikan bahwa telah tumbuh mikroorganisme pada media. Sampai mikroorganisme tumbuh diperlukan waktu selama 2 minggu. Hal tersebut dilakukan untuk didapatkan hasil sampai terjadi steady state pada kondisi air limbah. (Herlambang, 2002)

\section{E. Kiambang}

Kiambang (Salvinia Molesta) merupakan sejenis tumbuhan air yang mudah dikenali dan sering ditemui. Habitatnya hampir sama dengan teratai, hidup segar di kawasan berair seperti kolam, danau dan paya-paya air tawar. Agak berbeda dengan teratai, kiambang sejenis tumbuhan merayap atau mengapung di atas permukaan air dan cepat berkembang biak. Kiambang memiliki potensi untuk menjernihkan air limbah rumah tangga secara alami, tetapi air tersebut masih belum aman di konsumsi. Selain itu, dapat mengurangi polusi air sebagai tempat perkembangbiakan nyamuk dan bakteri penular penyakit.

\section{Metode Penelitian}

\section{A. Waktu dan Lokasi Penelitian}

\section{A.1 Waktu Penelitian}

Pengambilan sampel pada penelitian ini berasal dari limbah rumah makan Raja Laot yang berada di Jalan Imam Bonjol Pontianak pada siang hari, yaitu pada jam 14.00 WIB. Pengambilan sampel dilakukan dengan menggunakan gayung, kemudian dituang ke dalam jerigen plastik dengan kapasitas 30 liter. Penelitian ini dilakukan \pm 5 bulan pada bulan Januari - Mei 2013.

\section{A.2 Lokasi dan Tempat Penelitian}

Penelitian sampel dilakukan di Laboratorium Teknik Lingkungan, Fakultas Teknik Universitas Tanjungpura dan Analisa sampel dilakukan di laboratorium Fakultas Pertanian Universitas Tanjungpura

\section{B. Alat dan Bahan}

\section{B.1 Alat}

Alat yang digunakan dalam penelitian ini adalah kaca akuarium, media bioball, drum, ember, aerator, pompa, keran 3/4", selang. Berikut adalah spesifikasi media bioball yang digunakan, dapat dilihat pada Tabel 1 
Tabel 1 Spesifikasi Media Bioball yang digunakan

\begin{tabular}{rc}
\hline Tipe & Bio-ball \\
\hline Material & PVC \\
Bentuk & Bola \\
Ukuran & Diameter $3 \mathrm{~cm}$ \\
Warna & Hitam \\
\hline
\end{tabular}

\section{B.2 Bahan}

Bahan yang digunakan dalam penelitian ini adalah limbah cair rumah makan (greywater) dengan pengambilan limbah setiap harinya sebanyak $30 \mathrm{~L}$, media bioball sebanyak \pm 500 buah dan tanaman kiambang $3 / 4$ luas permukaan. Adapun rancangan reaktor penelitian dapat dilihat pada Gambar 1.

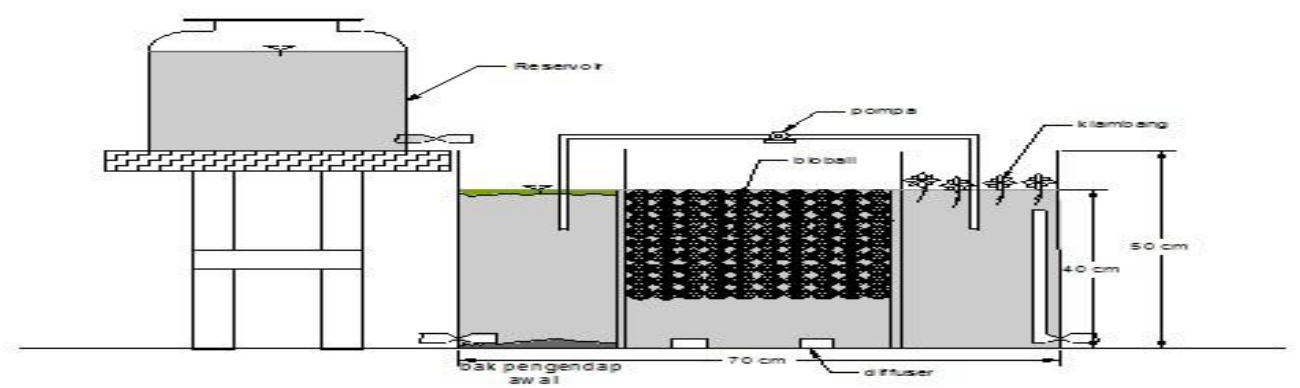

Gambar 1. Rancangan reaktor penelitian biofilter aerob

\section{Proses Pengembangbiakan Mikroorganisme (Seeding)}

Pembiakan (seeding) mikroorganisme dilakukan secara alami yaitu dengan cara mengalirkan air limbah yang akan diolah ke dalam reaktor yang telah terisi media bioball sampai terbentuknya lapisan biofilm pada media biofilternya, proses pembiakan dilakukan selama 2 (dua) minggu, hal tersebut dilakukan untuk didapatkan hasil sampai terjadi steady state pada kondisi air limbah. Tujuan dilakukan seeding selain untuk membenihkan dengan cara memasukkan kedalam air limbah yang akan dilakukan pengolahan supaya media mampu melakukan oksidasi pada zat pencemar organik pada air limbah tersebut dan menumbuhkan atau mengembangbiakan mikroorganisme agar dikondisikan dengan tempat beradaptasinya lingkungan awal, untuk tempat berkembang biaknya mikroorganisme yang akan di ujikan direaktor.

Setelah proses seeding selesai, dilakukan aklimatisasi atau pergantian limbah baru di dalam reaktor selama 3 (tiga) hari pada reaktor biofilter yang di dalamnya terdapat media bioball dan tanaman kiambang untuk mendapatkan suatu kultur yang bagus dan mikroorganisme yang mampu beradaptasi dengan air limbah. Aklimatisasi atau proses pergantian limbah ini dilakukan dengan cara mengalirkan air limbah ke dalam reaktor secara kontinyu selama 3 (tiga) hari dengan debit $0,34 \mathrm{ml} /$ detik.

\section{Hasil dan Pembahasan}

\section{A. Karakteristik Air Limbah}

Limbah rumah makan merupakan bahan organik yang umumnya terdiri dari unsur-unsur yang mudah terurai. Bahan organik yang terkandung dalam limbah rumah makan umumnya akan di dekomposisi oleh mikroorganisme melalui proses oksidasi menjadi bahan yang lebih sederhana dan unsur hara. Bahan organik yang terdapat pada limbah rumah makan akan dimanfaatkan oleh bakteri heterotrof sebagai bahan makanan. (Tri Apriadi, 2008)

Sampel air limbah diambil dari Rumah Makan Raja Laot yang berada di jalan Imam Bonjol Pontianak. Secara fisik, keadaan air limbah pada saat pengambilan terdapat cairan minyak yang 
sangat pekat dan berwarna kekuningan serta berbau tajam. Sebelum dilakukan penelitian, terlebih dahulu dilakukan pengujian kualitas air limbah domestik sebelum pengolahan untuk mengetahui karateristik air limbah tersebut pada Tabel 2

Tabel 2 Hasil Analisis Limbah Sebelum Pengolahan

\begin{tabular}{llccc}
\hline \multicolumn{1}{c}{ Parameter } & Alat/Metode & Satuan & $\begin{array}{c}\text { Kadar } \\
\text { Maksimum }\end{array}$ & $\begin{array}{c}\text { Baku Mutu } \\
(\mathrm{mg} / \mathrm{l})\end{array}$ \\
\hline $\mathrm{BOD}_{5}$ & Winkler-Azide & $\mathrm{mg} / \mathrm{l}$ & 758,50 & 100 \\
Minyak dan lemak & Gravimetrik & $\mathrm{mg} / \mathrm{l}$ & 5213 & 10 \\
$\mathrm{DO}$ & Winkler-Azide & $\mathrm{mg} / \mathrm{l}$ & 0 & - \\
$\mathrm{pH}$ & $\mathrm{pH}-\mathrm{meter}$ & $\mathrm{mg} / \mathrm{l}$ & 4,5 & $6-9$ \\
\hline
\end{tabular}

Dari Tabel 2 dapat dilihat bahwa limbah domestik rumah makan, memiliki tingkat pencemaran yang tinggi untuk parameter BOD, Minyak dan lemak jika tidak dilakukan pengolahan. Air limbah domestik tersebut melebihi baku mutu yang telah ditetapkan oleh Keputusan Menteri Lingkungan Hidup No.112 Tahun 2003 tentang Baku Mutu Air Limbah Domestik apabila langsung dibuang ke badan penerima, untuk itu perlu dilakukan pengolahan. Salah satu cara dengan pengolahan biofilter aerob menggunakan media bioball dan tanaman kiambang

\section{B. Pembiakan Mikroba (Seeding)}

Pembiakan (seeding) mikroorganisme pada penelitian dilakukan secara alami yaitu dengan cara mengalirkan air limbah domestik (greywater) secara terus menerus ke dalam reaktor biofilter yang telah terisi media bioball sampai terbentuknya lapisan biofilm pada media biofilternya selama \pm 2 minggu selama percobaan. Selama proses pembiakan dilakukan pemberian oksigen secara terus menerus dengan menginjeksikan oksigen ke dalam reaktor agar proses oksidasi biologi oleh mikroba dapat berjalan dengan baik. (E, Luluk dan Suprihatin, 2009)

Proses seeding diamati setiap hari, apabila pada media terbentuk lapisan lendir yang berwarna hitam kecoklatan-coklatan serta tidak mudah terlepas dari media, maka dapat dipastikan bahwa telah tumbuh mikroorganisme pada media. Jika senyawa organik yang ada mulai pecah oleh aktivitas bakteri dan adanya oksigen terlarut direduksi menjadi nol, maka warna biasanya berubah menjadi semakin gelap. (Metcalf dan Eddy, 2003)

Selama proses seeding, di dalam reaktor terjadi proses perkembangbiakkan bakteri yang melewati fase awal yakni fase lag yaitu bakteri baru beradaptasi dengan lingkungan barunya. Setelah itu barulah memasuki fase penambahan biomassa bakteri yang dikenal dengan fase eksponensial. Proses seeding dalam penelitian ini berlangsung selama 2 minggu agar terbentuknya mikroorganisme pada media bioball, yang ditandai dengan lapisan lendir diatas permukaan bioball, dapat dilihat pada Gambar 2

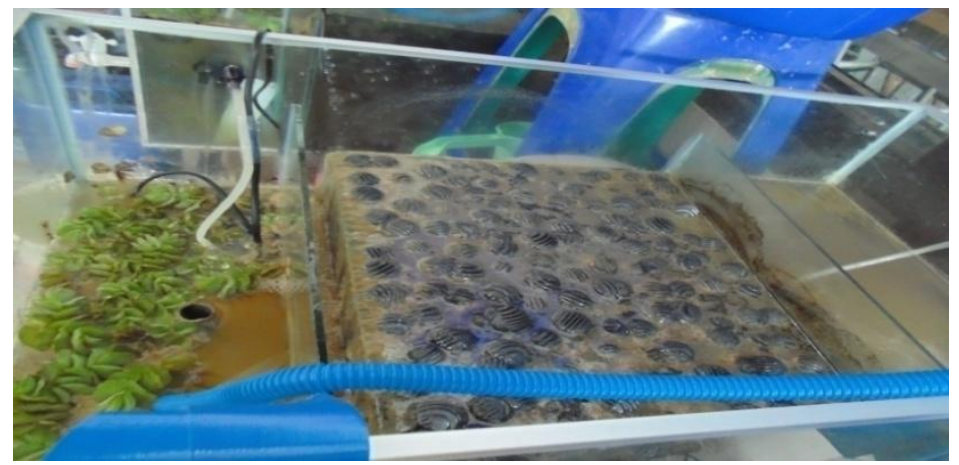

Gambar 2 Hasil seeding bioball 
Proses seeding ini berjalan selama 2 minggu, dilanjutkan dengan proses aklimatisasi, yaitu proses pemberian limbah baru ke dalam reaktor biofilter, aklimatisasi dilakukan untuk mendapatkan suatu kultur mikroorganisme yang stabil dan dapat beradaptasi dengan air limbah domestik (rumah makan). Proses aklimatisasi dilakukan untuk menghindari matinya bakteri yang telah di-seeding sebelumnya karena belum sempat beradaptasi dengan lingkungan baru. Proses aklimatisasi pada penelitian ini berlangsung selama 3 (tiga) hari, yaitu dengan cara mengalirkan air limbah yang berada di reservoir ke dalam reaktor biofilter secara perlahan dengan debit yang telah di tetapkan sebelumnya yaitu $0,34 \mathrm{ml} /$ detik.

\section{Penurunan BOD (Biochemical Oxigen Demand)}

Adapun hasil pemeriksaan berdasarkan hasil pemeriksaan di Laboratorium Fakultas Pertanian Universitas Tanjungpura, hasil parameter BOD dapat dilihat pada Tabel 3

Tabel 3. Hasil Parameter BOD (mg/L)

\begin{tabular}{ccccc}
\hline \multirow{3}{*}{ SAMPEL } & \multirow{2}{*}{$\begin{array}{c}\text { ANALISA } \\
\text { AWAL }\end{array}$} & HARI KE & \multicolumn{2}{c}{ ANALISA } \\
\cline { 4 - 5 } & & 1 & AKHIR & EFISIENSI \\
\hline \multirow{3}{*}{ BOD } & \multirow{2}{*}{758.5} & 2 & 235.68 & $43.88 \%$ \\
& & 3 & 296.61 & $68.98 \%$ \\
\hline
\end{tabular}

Berdasarkan Keputusan Menteri Lingkungan Hidup No. 112 tahun 2003, nilai BOD pada sampel air limbah rumah makan sebelum pengolahan sebesar $758,5 \mathrm{mg} / \mathrm{l}$ telah melebihi baku mutu yang diperbolehkan, yaitu $100 \mathrm{mg} / \mathrm{l}$. Dari penelitian yang telah dilakukan, pengolahan biofilter aerob dengan menggunakan media bioball dan tanaman kiambang mampu dalam menurunkan beban pencemar seperti BOD. Pada hari pertama (ke-1), percobaan dengan menggunakan bioball dan tanaman kiambang efisiensi penurunannya sebesar $43,88 \%$. Sedangkan pada hari (ke-2) efisiensi untuk bioball dan tanaman kiambang meningkat menjadi $68,98 \%$, peningkatan nilai efisiensi BOD ini terjadi akibat di dalam reaktor air limbah mengalami suatu proses penguraian materi organik yang dilakukan oleh mikroorganisme, dengan bantuan bioball dan tanaman kiambang. Menurut (Said, 2005) hal ini disebabkan karena adanya media bioball yang berfungsi sebagai media filter yang terbuat dari plastik berbentuk bulat dengan ronggarongga yang digunakan sebagai tempat tinggal bakteri atau mikroorganisme, dan juga karena adanya aktivitas mikroorganisme pada tanaman kiambang yang membantu menurunkan konsentrasi BOD pada air limbah domestik, karena kemampuan akar pada tanaman kiambang berfungsi sebagai alat penyerapan air dan unsur hara serta mineral.

Pada hari ke-3 percobaan dengan bioball dan tanaman kiambang efisiensinya menurun menjadi $60,90 \%$, dalam hal ini terjadi fase penurunan BOD yang diduga suplay oksigen dari blower bekerja kurang optimal, karena pipa penyalur blower tertutup oleh kotoran sehingga udara yang masuk berkurang, akibatnya penurunan BOD masih rendah, jika oksigen dalam akar tercukupi maka mikroorganisme yang berperan dalam penguraian limbah semakin besar.

Pada percobaan ini media bioball sebagai filter dalam pengolahan limbah dengan memanfaatkan mikroorganisme yang menempel pada media yang membentuk lapisan film untuk menguraikan zat organik yang terdapat pada limbah. Pada penelitian ini, influent akan melakukan kontak dengan bioball sehingga terjadi proses biokimia, akibatnya bahan organik yang terdapat dalam limbah cair dapat diturunkan kandungannya. (Metcalf dan Eddy, 2003).

Mengingat percobaan dilakukan dengan sistem kontinyu, maka dalam bak reaktor dapat terjadi penambahan nutrient baru yang dapat mendukung kehidupan mikroorganisme. Pada 
pertengahan waktu yaitu percobaan dengan media bioball dan tanaman kiambang pada hari (ke2), pertumbuhan mikroorganisme telah mencapai titik optimal terhadap ketersediaan nutrient atau telah memasuki fase stasioner, sedangkan pada hari ke-3 percobaan dengan bioball dan tanaman kiambang mengakibatkan naiknya parameter BOD, hal ini disebabkan karena mikroorganisme menuju fase kematian.

Terjadinya penurunan BOD pada penelitian ini terjadi pada proses biofilter oleh media bioball dan tanaman kiambang yang terdapat pada reaktor, media bioball mempunyai luas permukaan spesifik yang besar dan volume rongga (porositas) yang besar sehingga dapat melekatkan mikrooraganisme dalam jumlah yang besar. Hal ini juga dibantu dengan adanya tanaman kiambang dalam kemampuan sistem perakaran serta penyerapan hara yang membentuk filter dapat menahan partikel solid yang terdapat dalam air limbah, hal ini karena akar merupakan organ tanaman yang berfungsi sebagai alat penyerapan air dan unsur hara serta mineral (Haryanti, dkk, 2009)

Berikut Gambar grafik efesiensi BOD (Biochemical Oxigen Demand). Dapat dilihat pada Gambar 3.

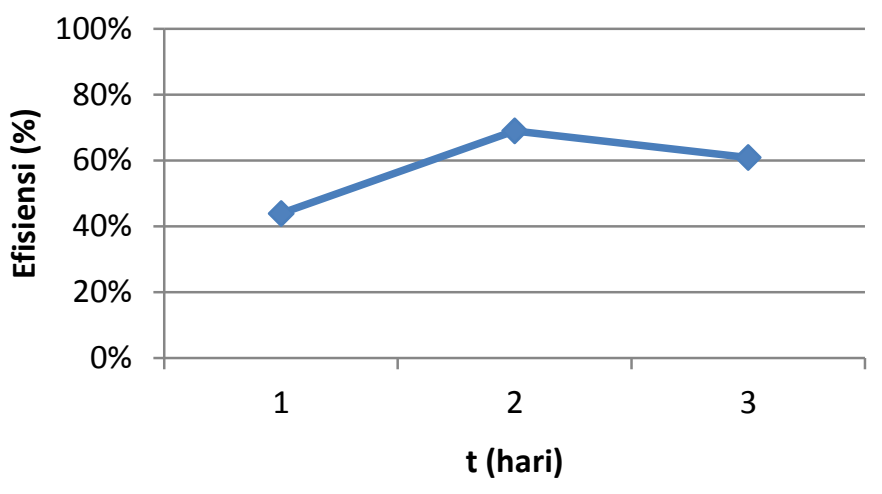

Gambar 3. Efesiensi BOD limbah cair rumah makan

Dari Gambar 3 diatas dapat dilihat bahwa efisiensi penurunan BOD yang optimal terjadi pada hari ke-2, dengan efisiensi 68,98\% pada hari tersebut nilai BOD mencapai titik terendahnya 235,29 $\mathrm{mg} / \mathrm{l}$ hal itu disinyalir karena terjadinya peningkatan biomassa mikroorganisme (dalam hal ini bakteri). Meningkatnya biomassa mikroorganisme akan menyebabkan turunnya konsentrasi bahan organik pada limbah. Peningkatan biomassa disebabkan oleh pertumbuhan mikroorganisme yang melekat pada rongga-rongga media filter bioball yang digunakan sebagai tempat tinggal mikroorganisme.

Pemilihan Salvinia molesta didasari penelitian Rahmansyah (2009) bahwa Salvinia molesta berpotensi sebagai tanaman hiperakumulator yang baik dengan pertumbuhan dan kelangsungan hidup. Selain itu Salvinia molesta mampu tumbuh pada nutrisi yang rendah.

Pada penelitian yang telah dilakukan, konsentrasi BOD masih diatas Baku Mutu Keputusan Menteri Lingkungan Hidup No.112 Tahun 2003, yaitu konsentrasi yang diperbolehkan untuk parameter BOD sekitar $100 \mathrm{mg} / \mathrm{L}$. Dengan penurunan konsentrasi BOD mengindikasikan bahwa bahan organik yang terkandung dalam air limbah sebagian besar merupakan bahan organik yang bersifat biodegradable (dapat terdegradasi secara biologis).

\section{Penurunan Minyak dan Lemak}

Berdasarkan hasil pemeriksaan di Laboratorium Fakultas Pertanian Universitas Tanjungpura, hasil penelitian untuk parameter Minyak lemak dapat dilihat pada Tabel 4 
Tabel 4 Hasil Parameter Minyak Lemak (mg/L)

\begin{tabular}{lllll}
\hline \multirow{2}{*}{ SAMPEL } & \multirow{2}{*}{$\begin{array}{c}\text { ANALISA } \\
\text { AWAL }\end{array}$} & HARI KE & $\begin{array}{l}\text { PNALISA } \\
\text { AKHIR }\end{array}$ & EFISIENSI \\
\hline \multirow{2}{*}{ MINYAK } & \multirow{2}{*}{5213} & 1 & 2465 & $52.71 \%$ \\
LEMAK & & 2 & 831 & $84.06 \%$ \\
& & 3 & 177.5 & $96.60 \%$ \\
\hline
\end{tabular}

Dari Tabel 4 diatas dapat dilihat bahwa pada percobaan dengan media bioball dan tanaman kiambang pada hari ke-1 efisiensinya sebesar $52,71 \%$, sedangkan pada hari ke-2 efisiensinya meningkat menjadi $84,06 \%$, hal ini disebabkan adanya kandungan nutrient yang melimbah pada reaktor biofilter. Pada hari ke-3, bakteri memasuki fase optimum untuk pengolahan dengan bioball dan tanaman kiambang semakin hari semakin meningkat, dapat dilihat dengan efisiensi penurunan sebesar $96,60 \%$ hal ini dikarenakan kandungan minyak yang berada dalam reaktor telah tersaring pada akar kiambang. Dapat dilihat bahwa tanaman kiambang berpengaruh terhadap penurunan minyak lemak karena adanya aktifitas mikroorganisme dalam sistem perakaran (Rhizosfer) yang terdapat dalam reaktor. Akar tanaman dapat meningkatkan kepadatan dan aktivitas mikroba yang disediakan oleh permukaan akar untuk pertumbuhan mikroba. (Vymazal 2008).

Adanya aktivitas mikroorganisme yang tumbuh pada media bioball dalam reaktor mendegradasi sebagian besar bahan organik dalam air limbah, tentu akan mempengaruhi konsentrasi Minyak Lemak pada awal penelitian. Menurut Nababan (2008), bakteri memiliki peran yang sangat penting dalam biodegradasi limbah minyak, sehingga faktor yang mempengaruhi pertumbuhan bakteri juga berdampak pada keberhasilan proses biodegradasi. Faktor-faktor yang dapat mempengaruhi proses biodegradasi antara lain suhu, $\mathrm{pH}$, keadaan nutrisi, dan ketersediaan O2. Sedangkan pada tanaman, akar tanaman berfungsi sebagai filtrasi dan mampu mengadsorpsi padatan tersuspensi serta tempat hidup mikroorrganisme yang mampu menghilangkan unsur hara.

Proses filtrasi dilakukan oleh media bioball dan pada akar tanaman kiambang yang terdapat dalam reaktor, terjadinya proses tersebut terjadi karena kemampuan partikel-partikel media maupun sistem perakaran membentuk filter yang dapat menahan partikel-partikel solid yang terdapat dalam air limbah. Berikut Gambar grafik efisiensi minyak lemak dapat dilihat pada Gambar 4

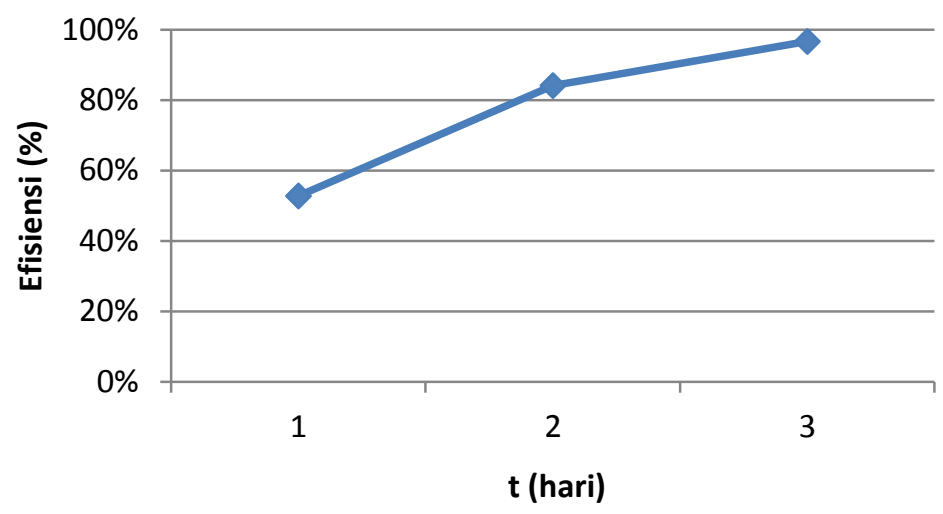

Gambar 4. Grafik efesiensi penurunan minyak lemak

Konsentrasi minyak lemak menurun seiring dengan bertambahnya waktu pengolahan. Dari hasil penelitian yang dilakukan, tanaman kiambang memiliki potensi untuk menjernihkan air 
limbah rumah makan terutama dalam menurunkan kandungan pencemar khususnya parameter dan minyak lemak. Walaupun dengan adanya tanaman kiambang dapat menurunkan beban pencemar, minyak lemak, tetapi nilai tersebut masih di atas baku mutu Keputusan Menteri Lingkungan Hidup No.112 Tahun 2003.

\section{Kesimpulan dan Saran}

A. Kesimpulan

Berdasarkan hasil penelitian yang telah dilakukan, pengolahan limbah cair rumah makan dengan biofilter aerob dengan menggunakan media bioball dan tanaman kiambang (Salvinia Molesta) mampu menurunkan kandungan BOD tertinggi dengan efisiensi 68,98\% dari kadar BOD awal sebesar 758,5 mg/l dan penurunan minyak lemak dengan efisiensi sebesar $96,60 \%$ dari kadar awal 5213 mg/l. Dari hasil penelitian yang sudah dilakukan, kandungan BOD, minyak dan lemak yang telah diolah dengan biofilter aerob menggunakan media bioball dan tanaman kiambang masih di atas baku mutu Keputusan Menteri Lingkungan Hidup No.112 Tahun 2003 untuk BOD sebesar $100 \mathrm{mg} / \mathrm{L}$ dan Minyak lemak sebesar $10 \mathrm{mg} / \mathrm{L}$.

B. Saran

Berdasarkan hasil yang telah didapat dalam penelitian ini, maka perlu dilakukan kajian lebih lanjut yaitu dibutuhkan pengolahan pendahuluan (pretreatment) untuk mengolah minyak dan lemak yang terkandung dalam limbah cair domestik akibat kegiatan memasak. Pengolahan pendahuluan dapat berupa oil and grease trab, untuk mengurangi kandungan BOD serta minyak lemak yang ada pada limbah rumah makan, sebelum dilakukan pengolahan dengan biofilter aerob

\section{Referensi}

Edahwati, L dan Suprihatin. 2009. Kombinasi Proses Aerasi, Adsorpsi dan Filtrasi pada Pengolahan Limbah Industri Perikanan. Jurnal Ilmiah Teknik Lingkungan; Vol.1 No.2

Haryanti, Sri, Nintya Setiari, Rini Budi Hastuti, Endah Dwi Hastuti, dan Yulita Nurchayati. 2009. Respon Fisiologi dan Anatomi Eceng Gondok di Berbagai Perairan Tercemar. Jurnal Penelitian Sains dan Teknologi. Vol.10,No1:30-40.

Herlambang, A. 2002. Teknologi Pengolahan Limbah Cair Industri Tahu. Pusat Pengkajian dan Penerapan Teknologi Lingkungan (BPPT) dan Badan Pengendalian Dampak Lingkungan Samarinda

Herlambang, A dan R. Marsidi. 2003. Proses Denitrifikasi dengan Sistem Biofilter untuk Pengolahan Air Limbah yang Mengandung Nitrat. Jurnal Teknologi Lingkungan; Vol 4 (1): 46-55

Metcalf dan Eddy, Inc. 2003. Wastewater Engineering: Treatment, Disposal and Reuse. McGraw-Hill, Inc: USA.

Said, N. 2005. Aplikasi bioball untuk media biofilter strudi kasus pengolahan air limbah pencucian jeans. Pusat Pengkajian dan Penerapan Teknologi Lingkungan (BPPT). Jurnal; Vol 1 No.1

Tri Apriadi, 2008. Jurnal Kombinasi bakteri dan tumbuhan air sebagai bioremediator dalam mereduksi kandungan bahan organik limbah kantin. INSTITUT Pertanian Bogor 2008

Wijeyekoon, S., Mino T., Satoh, H., dan Matsuo, T. 2000. Growth and novel Structural features of tubular biofilms. Journal water science and technology. 